УДК 349.2(477)-057.19

DOI https://doi.org/10.32844/2618-1258.2019.6.19

ЮРОВСЬКА В.В.

\title{
НОВЕЛИ ПРАВОВОГО РЕГУЛЮВАННЯ ОТРИМАННЯ СТАТУСУ БЕЗРОБІТНОГО В УКРАЇНI
}

У статті аналізуються новели правового регулювання отримання особою статусу безробітного. Автор зосереджує увагу на запровадженні інституту кар'єрного радника та профілювання безробітного або особи, яка шукає роботу. Автор робить висновок, що кар'єрний радник має сприяти працевлаштуванню особи, яка має кваліфікацію та навички, які користуються попитом на ринку праці, як наслідок, роботодавець має бути задоволений швидкістю підбору працівника, який відповідає його потребам.

Автор стверджує, що кар'єрні радники насамперед покликані надавати послуги та нести відповідальність за сприяння у працевлаштуванні з огляду на інтереси клієнта. Під час надання послуг кар'єрний радник повинен бути ланкою між клієнтом та потенційним роботодавцем. Тому ключовим показником ефективності їх роботи $є$ швидкість та якість працевлаштування особи.

У статті доводиться, що кар'єрні радники є індивідуальними консультантами осіб, які шукають роботу, та зареєстрованих безробітних у пошуку роботи, плануванні кар'єри та підвищенні конкурентоспроможності на ринку праці, у тому числі через залучення до системи професійного навчання впродовж життя.

Кар'єрний радник супроводжує та направляє особу, іноді коригує іiї дії, однак саме особа, яка шукає роботу, відіграє активну роль. Послуги кар'єрного радника для зареєстрованих безробітних характеризуються більш активною участю кар'єрного радника, однак не передбачають пасивної поведінки з боку зареєстрованих безробітних. Зареєстровані безробітні мають можливість не лише отримати нову роботу, а й підвищити професійну кваліфікацію та розвити професійні навички за рахунок Фонду загальнообов'язкового державного соціального страхування на випадок безробіття, тоді як у осіб, які шукають роботу, така можливість обмежена безоплатними лекціями та семінарами загального характеру, які проводяться самими центрами зайнятості чи їх партнерами.

Разом з цим автор наголошує, що зобов'язання кар'єрного радника не означають пасивної поведінки особи, яка шукає роботу. Вона також повинна шукати роботу, повідомляти кар'єрного радника про самостійно підібрані вакансії для того, щоб кар'єрний радник провів переговори з роботодавцем щодо умов майбутнього працевлаштування. У разі потреби кар'єрний радник може супроводжувати особу на співбесіди з потенційним роботодавцем.

Ключові слова: безробіття, реєстрація безробітного, пошук роботи, кар'єрний радник, профілювання безробітного.

The article analyzes the innovations in the legal regulation of obtaining a person of the unemployed status. The author focuses on the establishment of a career advisor and the profiling of an unemployed person or a job seeker. The author concludes that career advisor should facilitate the employment of a person who has the skills that are in demand in the labour market, and as a result the employer must be satisfied with the speed of recruiting a worker who meets his needs.

The author argues that career advisors primarily intended to provide services and be responsible for the promotion of employment on the basis of the interests of the client. When providing services, the career Advisor needs to be a link between the client and the potential employer. Therefore, a key indicator of their effectiveness is the speed and quality of employment of the person.

ЮРОВСЬКА В.В. - доктор юридичних наук, доцент, доцент кафедри трудового права (Національний юридичний університет імені Ярослава Мудрого) 
This article argues that career advisors are individual consultants for job seekers and unemployed job search, the career planning and competitiveness on the labour market, including through the involvement in professional learning throughout life.

The career advisor supports and guides the person sometimes corrects her actions, but it is the person who is looking for a job, playing an active role. Career consultant for the unemployed was characterized by more active involvement of the career adviser, but does not include passive behavior on the part of the registered unemployed. Registered unemployed have the opportunity not only to get a new job, but also to enhance their professional qualifications and develop professional skills at the expense of Fund of obligatory state social insurance against unemployment, while individuals who are looking for work, this opportunity is limited to free lectures and seminars of a General nature, carried out by the employment centres or their partners.

However, the author notes that the duties of a career Counsellor does not mean passive behavior of the person who is looking for work. It also needs to look for a job, let career adviser about a self-chosen jobs to career Advisor held talks with the employer regarding the terms and conditions of future employment. If necessary, the career advisor can accompany the person to the interview with a potential employer.

Key words: unemployment, unemployment registration, job search, career advisor, profiling of the unemployed.

Вступ. Безробіття здійснює негативний вплив як в економічному, так і соціальному плані, адже зростання цього показника створює цілу низку проблем: скорочення обсягів виробництва валового національного продукту; зниження податкових надходжень до державного бюджету; зростання витрат на соціальну допомогу безробітним; знецінення наслідків навчання; посилення соціальної напруженості; зниження трудової активності тощо. Незайнята робоча сила свідчить про недовикористання економічного потенціалу суспільства, прямі економічні втрати, що є наслідком природного й фактичного безробіття.

Проблема безробіття набуває світового масштабу, а отже, й заходи щодо боротьби з цим явищем мають бути чітко виваженими та дієвими. Сутність безробіття полягає в тому, що це не випадкове, а закономірне явище, породжене процесом нагромадження капіталу в умовах ринкової економіки, основаної на приватній власності, на засоби виробництва. Ринкова економіка за таких умов неминуче породжує безробіття, у сільському господарстві та промисловості зайнятість продовжує скорочуватися. Позитивні зрушення в сфері зайнятості можуть лише частково скоротити дефіцит робочих місць, якщо це буде супроводжуватися активними політичними зусиллями, спрямованими на підвищення якості робочих місць і продуктивності в секторі послуг $[1$, с. 5,6$]$.

В Україні в III кварталі 2018 року кількість зайнятого населення віком 15-70 років становила 16,7 млн осіб, а кількість безробітних відповідного віку - 1,4 млн осіб. У листопаді 2018 року в Україні було офіційно зареєстровано 301,0 тисяч безробітних [2]. 3 метою зменшення рівня безробіття в державі провадиться активна соціальна політика. Так, Кабінет Міністрів України своєю постановою від 19.09.2018 р. № 792 затвердив новий Порядок реєстрації, перереєстрації безробітних та ведення обліку осіб, які шукають роботу [3]. Цим Порядком передбачається низка новел у правовому регулюванні реєстрації безробітних, що викликає необхідність їх ретельного аналізу.

Аналіз останніх досліджень і публікацій з теми. Наукові дослідження з питань зайнятості населення, захисту трудових прав громадян в умовах безробіття провадилися такими вченими, як А.Ю. Бабаскін, Т.В. Маркіна, В.П. Пастухов, М.П. Головко, О.С. Мачульська, І.О. Гуменюк, М.І. Боднарук, О.В. Москаленко, В.В. Юровська та інші. Однак ці наукові здобутки сьогодні недостатньо повно відображають ті зміни, які відбуваються на ринку праці та впливають на рівень зайнятості в країні, тому доцільним $є$ проведення досліджень нинішнього стану зайнятості та безробіття в Україні. При цьому центральним буде питання щодо правового регулювання отримання статусу безробітного та соціальний захист таких осіб.

Постановка завдання. Метою цієї статті $є$ аналіз новел у правовому регулюванні отримання статусу безробітного в сучасних умовах та вироблення пропозицій щодо його удосконалення.

Результати дослідження. Відповідно до ст. 43 Закону України «Про зайнятість населення» [4] статусу безробітного може набути: 1) особа працездатного віку до призначення пенсії (зокрема, на пільгових умовах або за вислугу років), яка через відсутність роботи не має заробітку або інших передбачених законодавством доходів, готова та здатна приступити до роботи; 
2) інвалід, який не досяг встановленого ст. 26 Закону України «Про загальнообов'язкове державне пенсійне страхування» пенсійного віку та отримує пенсію по інвалідності або соціальну допомогу відповідно до законів України «Про державну соціальну допомогу інвалідам з дитинства та дітям-інвалідам» та «Про державну соціальну допомогу особам, які не мають права на пенсію, та інвалідам»; 3) особа, молодша 16-річного віку, яка працювала і була звільнена у зв'язку із змінами в організації виробництва і праці, зокрема припиненням або перепрофілюванням підприємств, установ та організацій, скороченням чисельності (штату) працівників.

Варто звернути увагу, що положення цієї статті не узгоджуються із наведеними у цьому ж Законі визначеннями правових категорій «безробітний», «зареєстрований безробітний» та «особа працездатного віку». Так, у ст. 1 Закону [4] встановлено, що безробітний - особа віком від 15 до 70 років, яка через відсутність роботи не має заробітку або інших передбачених законодавством доходів як джерела існування, готова та здатна приступити до роботи. Зареєстрований безробітний - особа працездатного віку, яка зареєстрована в територіальному органі центрального органу виконавчої влади, що реалізує державну політику у сфері зайнятості населення та трудової міграції, як безробітна і готова та здатна приступити до роботи. Тоді як особами працездатного віку визнано осіб віком від 16 років, які не досягли встановленого ст. 26 Закону України «Про загальнообов'язкове державне пенсійне страхування» пенсійного віку.

Тобто із аналізу наведених приписів вбачається, що не зможуть бути зареєстрованими як безробітні: (а) особи віком 14 та 15 років, позаяк особами працездатного віку визнано лише осіб віком від 16 років, що суперечить положенням КЗпП України [5], оскільки у ст. 188 визначено, що особа може бути допущена до роботи не лише з 16 років, але й 314 та 15 років 3 дотриманням встановлених умов, а відповідно - ці особи також є особами працездатного віку; (б) особа, яка вже досягла пенсійного віку (наразі 60 років), бо такі особи за визначенням осіб працездатного віку до них не належать, хоча безробітними визнаються особи віком до 70 років. Отже, ці категорії осіб не отримають статусу зареєстрованого безробітного, а тому позбавляються права на реалізацію чималої кількості прав та гарантій, зокрема, на матеріальне забезпечення на випадок безробіття. У зв'язку з цим такі особи матимуть статус осіб, які шукають роботу, тобто особи, яким не може бути надано в установленому порядку статус безробітного або відмовлено у наданні такого статусу. Тому доречним буде внести зміни до визначення поняття осіб працездатного віку, зокрема, передбачивши, що ними є особи віком від 16 років (у виняткових випадках від 14 та 15 років), які не досягли встановленого ст. 26 Закону України «Про загальнообов’язкове державне пенсійне страхування» пенсійного віку, а у визначенні правової конструкції «безробітний» слова «особа віком від 15 до 70 років» виключити, замінивши на «особа працездатного віку».

Із 1 січня 2019 року набрав чинності Порядок реєстрації та перереєстрації безробітних та ведення обліку осіб, які шукають роботу [3]. Цей Порядок передбачає низку новел у правовому регулюванні процедури отримання статусу безробітного. Так, запроваджується інститут кар'єрного радника, який сприятиме особам, які шукають роботу, та зареєстрованим безробітним у пошуку роботи, плануванні кар'єри. Крім того, запроваджується профілювання безробітного або особи, яка шукає роботу, зокрема, оцінюватиметься можливість їх працевлаштування, ступінь мотивації до праці. За результатом первинного профілювання кар'єрний радник разом з особою, яка шукає роботу, складатимуть індивідуальний план надання послуг з працевлаштування.

Кар'єрні радники насамперед покликані надавати послуги та нести відповідальність за сприяння у працевлаштуванні з огляду на інтереси клієнта. Під час надання послуг кар'єрний радник повинен бути ланкою між клієнтом та потенційним роботодавцем. Тому ключовим показником ефективності їх роботи є швидкість та якість працевлаштування особи.

Запровадження інституту кар'єрного радника стало можливим завдяки співпраці Державної служби зайнятості (Центрального апарату) з Проектом Міжнародної організації праці «Інклюзивний ринок праці для створення робочих місць в Україні». 39 січня 2019 року Державна служба зайнятості України розпочала цикл тренінгів. Перший тренінг було проведено для фахівців базових центрів зайнятості та філій Київського обласного центру зайнятості, які будуть виконувати функції реєстраторів [6].

Тобто кар'єрні радники є індивідуальними консультантами осіб, які шукають роботу, та зареєстрованих безробітних у пошуку роботи, плануванні кар'єри та підвищенні конкурентоспроможності на ринку праці, у тому числі через залучення до системи професійного навчання впродовж життя.

Залежно від статусу клієнта центру зайнятості (особа, яка шукає роботу чи зареєстрований безробітний) визначається обсяг послуг, які має надавати кар'єрний радник. Послуги осо- 
бам, які шукають роботу, мають більш консультаційний та супроводжувальний характер. Такі послуги спрямовані на сприяння особі в управлінні кар'єрою, адаптації до потреб роботодавців, розвиткові необхідних навичок. Кар'єрний радник супроводжує та направляє особу, іноді коригує її дії, однак саме особа, яка шукає роботу, відіграє активну роль. Послуги кар'єрного радника для зареєстрованих безробітних характеризуються більш активною участю кар'єрного радника, однак не передбачають пасивної поведінки з боку зареєстрованих безробітних. Зареєстровані безробітні мають можливість не лише отримати нову роботу, а й підвищити професійну кваліфікацію та розвити професійні навички за рахунок Фонду загальнообов'язкового державного соціального страхування на випадок безробіття, тоді як у осіб, які шукають роботу, така можливість обмежена безоплатними лекціями та семінарами загального характеру, що проводяться самими центрами зайнятості чи їх партнерами. Сприяння професійному розвитку впродовж життя стає одним із ключових принципів у роботі Державної служби зайнятості. Певним недоліком у роботі центрів зайнятості було те, що його працівники формально направляли безробітних для навчання лише у власні освітні центри або навчальні заклади за обмеженим переліком програм. За нинішніх умов, вважаємо, доцільно звернути увагу на програми неформального професійного навчання, які реалізуються за участі роботодавців та відповідають потребам ринку праці. Інший аспект, на який варто звернути увагу, - не всім зареєстрованим безробітним необхідно проходити нове навчання, тому кар'єрні радники мають критично аналізувати результати поглибленого профілювання.

Для того щоб кар'єрні радники працювали відповідно до нового підходу обслуговування клієнтів, розділяли його та займали активну позицію в удосконаленні взаємодії з клієнтами, представники Мінсоцполітики, Державної служби зайнятості, Інституту підготовки кадрів державної служби зайнятості України, Офісу реформ КМУ, проекту Міжнародної організації праці «Інклюзивний ринок праці для створення робочих місць в Україні» працюють над розробленням профілю кар'єрного радника, вимогами для проведення відбору кар'єрних радників, програмою підготовки тренерів для проведення навчання відібраних кар'єрних радників у майбутньому, програмою навчання кар'єрних радників. Також буде представлено програму адаптації кар'єрних радників до нових вимог, систему оцінки цілей та ключових результатів та інші документи, необхідні для забезпечення ефективності та продуктивності роботи кар'єрних радників.

Особа, яка має підстави бути зареєстрованим безробітним, незалежно від того, чи зверталася вона до центру зайнятості як особа, яка шукає роботу, чи ні, для отримання спеціальних послуг має бути зареєстрована як безробітна на підставі заяви, форма якої затверджена Мінсоцполітики. Особа, яка ризикує стати безробітним або на момент звернення вже не має роботи, користується пріоритетним правом на сприяння у працевлаштуванні. Сучасний розвиток ринку праці потребує створення умов для відсутності або максимального скорочення перехідного періоду у разі зміни місця роботи або зміни виду зайнятості. Тому будь-яка особа перед отриманням статусу зареєстрованого безробітного отримує підтримку та сприяння у працевлаштуванні 3 боку кар'єрного радника як особа, що шукає роботу. Зобов'язанням кар'єрного радника $є$ надання допомоги особі працевлаштуватися протягом семи календарних днів 3 дня звернення. Для цього кар'єрний радник підбирає особі вакансії, які можуть її задовольнити та на які вона може погодитися протягом зазначеного строку, перевіряє актуальність вакансії, узгоджує з роботодавцем та з особою, яка шукає роботу, умови проведення співбесіди, умови праці, а також надає особі консультації щодо проходження співбесіди. Такі зобов'язання кар'єрного радника не означають пасивної поведінки особи, яка шукає роботу. Вона також повинна шукати роботу, повідомляти кар'єрного радника про самостійно підібрані вакансії для того, щоб кар'єрний радник провів переговори з роботодавцем щодо умов майбутнього працевлаштування. У разі потреби кар'єрний радник може супроводжувати особу на співбесіди з потенційним роботодавцем. Якщо протягом семи календарних днів особа, яка шукає роботу, не працевлаштовується, або якщо роботодавець не прийняв остаточного рішення про працевлаштування такого кандидата, особа отримує статус безробітного з дня подання відповідної заяви. Отже, рішення про надання статусу безробітного чи відмову у наданні такого статусу приймається центром зайнятості не пізніше сьомого календарного дня з дня подання особою, яка шукає роботу, заяви про надання статусу безробітного.

Якщо зареєстрований безробітний відмовляється від підписання індивідуального плану працевлаштування, то він втрачає статус зареєстрованого безробітного та право на отримання матеріального забезпечення на випадок безробіття. Підписавши договір, зареєстрований безробітний підтверджує серйозність наміру працевлаштуватися або розпочати власну справу та го- 
товність діяти, аби цього досягти. Водночас зареєстрований безробітний набуває право вимагати від кар'єрного радника виконання зобов'язань, а також доводити його бездіяльність у разі незадовільної роботи.

Висновки. Кар'єрні радники стають новими лідерами Державної служби зайнятості України, а від якості іх роботи буде залежати ефективність співпраці осіб, які шукають роботу, зареєстрованих безробітних, роботодавців з Державною службою зайнятості України. Запровадження інституту кар'єрного радника має сприяти досягненню такого результату: працівник працевлаштований, має кваліфікацію та навички, які користуються попитом на ринку, психологічно готовий до роботи на умовах, визначених роботодавцем, керуючись його корпоративною культурою, а роботодавець задоволений швидкістю підбору працівника, який відповідає його потребам, та повертається до центру зайнятості добровільно.

\section{Список використаних джерел:}

1. Москаленко О.В. Правове забезпечення соціального захисту безробітних в Україні : монографія. Харків : Юрайт, 2018. 192 с.

2. Держстат оприлюднив кількість безробітних за міжнародною методологію. URL: https://www.rbc.ua/ukr/news/gosstat-obnarodoval-kolichestvo-bezrabotnyh-1545816306.html (дата звернення 26.02.2019).

3. Про затвердження Порядку реєстрації, перереєстрації безробітних та ведення обліку осіб, які шукають роботу: постанова Кабінету Міністрів України від 19.09.2018 р. № 792 . Oфiüiüний вісник України. 2018. № 80. Ст. 2662.

4. Про зайнятість населення: Закон України від 05.07.2012 p., № 5067-VI. Вiдомості Bepховної Ради. 2013. № 24. Ст. 243.

5. Кодекс законів про працю України : Закон України від 10.12.1971 р., № 322-VIII. Biдом. Верхов. Ради УРСР. 1971. Дод. № 50. Ст. 375.

6. У службі зайнятості тепер є єдиний куратор для безробітних. URL: http://procherk.info/ news/7-cherkassy/70067-u-sluzhbi-zajnjatosti-teper-e-edinij-kurator-dlja-bezrobitnih (дата звернення 26.02.2019). 